\title{
Exploring the Path of Innovation and Entrepreneurship of Small and Micro Enterprises
}

\author{
Dong Yang \\ Youth League, Xi'an Eurasia University, Xi'an, Shaanxi, China, 710065
}

Keywords: small and micro enterprises; innovation and entrepreneurship; the path

\begin{abstract}
Small and micro businesses are the backbone of China's national economic development, the mainstay of innovation and entrepreneurship practice and an important support force for China's social economy. With the slogan of "mass entrepreneurship and innovation", China has launched a wave of innovation and entrepreneurship. The innovation and entrepreneurship of small and medium-sized enterprises are faced with great opportunities, but at present, small and micro enterprises in China still face challenges such as high threshold of entrepreneurship, lack of financing channels and shortage of talents, which have greatly influenced the development of small and micro enterprises in China. So, this paper has important practical significance for the innovation and entrepreneurship development of small and micro enterprises. This paper analyzes the current situation of innovation and entrepreneurship development of small and micro enterprises in China, and then analyzes the problems and solutions to provide a new way for the development of small and micro businesses in China.
\end{abstract}

\section{Introduction}

The innovation and entrepreneurship development of small and micro businesses will be affected by internal and external factors in China. This paper analyzes these internal and external factors. It is also helpful for the innovation and entrepreneurship development of small and micro enterprises in China. The Chinese government divides the environmental indicators of innovation and entrepreneurship in China into two aspects: hardware and software. The hardware environment is the infrastructure and natural environment of China's social and economic market. Software refers to the talents, culture, financing, laws and regulations, policies and other aspects of Chinese society. After premier li keqiang put forward the development strategy of "mass innovation and mass entrepreneurship" in 2015, China has responded actively and vigorously launched innovation and entrepreneurship. However, there are many problems in the development of small and micro enterprises in China. These problems seriously restrict the innovation and entrepreneurship of small and micro enterprises in China.

\section{Analysis of Innovation and Entrepreneurship of Small and Micro Enterprises}

\subsection{The relatively high threshold of registration}

Although there have been major changes in the business place, registered capital and related procedures in the registration of small and micro enterprises in China, it is still cumbersome and the threshold for registration is still high. When registering for registration, the legal person shall have strict restrictions on the place, scope and name of the operation. In addition, with the large number of red tape involved in registration, this situation severely restricted the development of small and micro enterprises' innovation and entrepreneurship.

\subsection{Narrow financing channels and financing difficulties}

Small and micro businesses are often faced with insufficient funds due to their small size. And capital is the important factor that restricts small and micro enterprise innovation and entrepreneurship development. According to the survey, small and micro businesses in China 
account for only about $15 \%$ of China's total credit, and $76 \%$ of small and micro businesses are underfunded. This is mainly because Banks and other financial institutions are limited to small and micro enterprise credit and small and micro enterprise financing channels narrow two aspects. Small and micro businesses are weak in their own infrastructure, and their loans are generally "short, small, frequent and urgent". However, the bank loans are slow to approve and the mortgage guarantee demand, etc., causes small and micro enterprises to not get the loan in time. According to the survey, $37 \%$ of small and micro businesses in China think the procedures are cumbersome and $39 \%$ of small and micro businesses believe they cannot get a loan because of a lack of responsive collateral. In reality, the financing of small and micro businesses is usually financed by private loans and suppliers' credit. The other financing channels of small and micro enterprises are relatively narrow, they cannot obtain long-term financial support, and they are less able to bear market risks.

\subsection{Heavy burden on enterprises}

China's small and micro businesses are increasingly burdened by the rising cost of labor and raw materials. According to statistics from China's statistics bureau, labor costs have become a prominent problem for small and micro businesses in China. In addition, with the increase of prices, rents, logistics and other cost increases in China. And Chinese taxes have been high, and these are squeezing the profits of small and micro businesses.

\subsection{Lack of talents and innovation}

Talent is the driving force of enterprise development, and enterprises can make great progress only by obtaining innovative talents. However, high-end talents tend to be concentrated in large enterprises and institutions, and small and micro enterprises account for very few high-end talents. However, the lack of responsive technical innovation talents and management talents is a major problem for small and micro enterprises.

\section{Construction of Promotion Mechanism for Innovation and Entrepreneurship of Small and Micro Enterprises}

\subsection{The dynamic propulsion mechanism for innovation and entrepreneurship of small and micro enterprises}

Talent is the driving force of enterprise development. Only innovation and entrepreneurship can achieve core competitiveness. And the motivation for innovation and entrepreneurship is the goal that entrepreneurs want to succeed. This dynamic instructs entrepreneurs to move forward from traditional high input and high consumption to new and innovative production. This paper adapts to the development of The Times and formulates the dynamic propulsion mechanism of small and micro enterprises' innovation and entrepreneurship, as shown in figure 1.

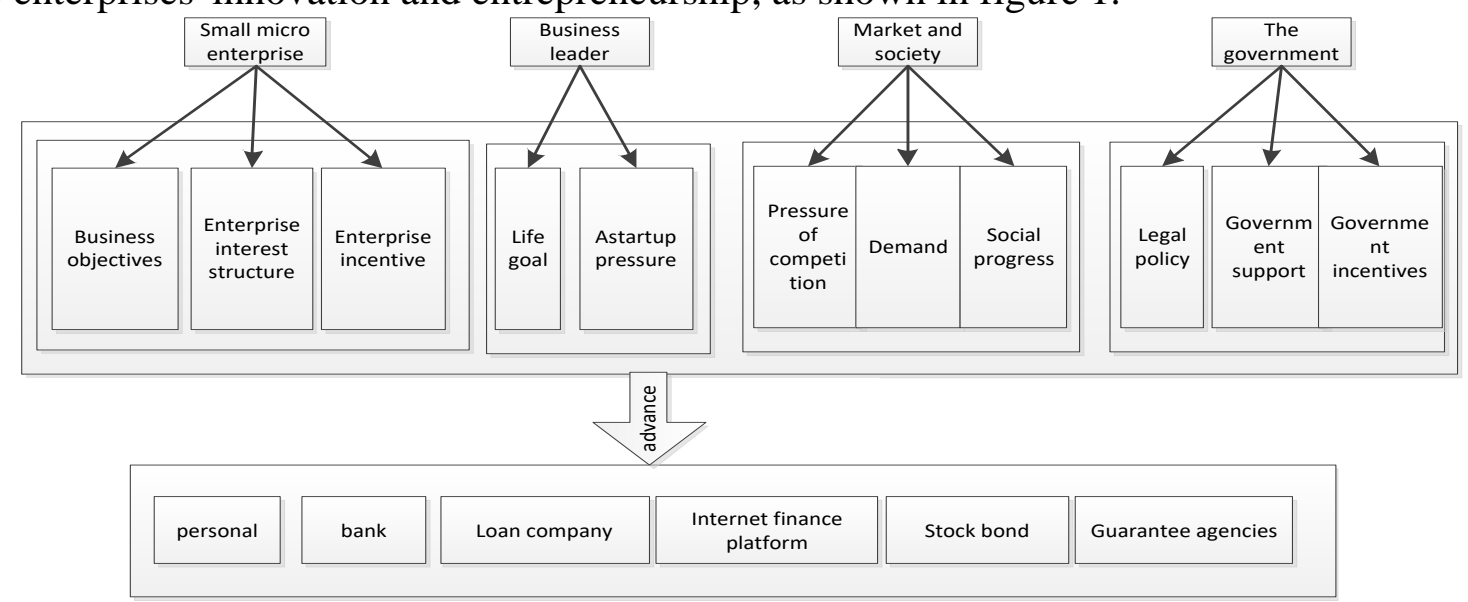

Figure 1. The dynamic propulsion mechanism of small and micro enterprises innovation and entrepreneurship 


\subsection{Financing mechanism for innovation and entrepreneurship of small and micro enterprises}

Financing difficulty has become a major problem of innovation and entrepreneurship of small and micro enterprises. Solving financing problem has become the core and key of innovation and entrepreneurship of small and micro enterprises. Small and micro businesses can finance themselves through direct and indirect financing. This paper expounds the financing mechanism of small and micro enterprises through traditional financing and new financing.

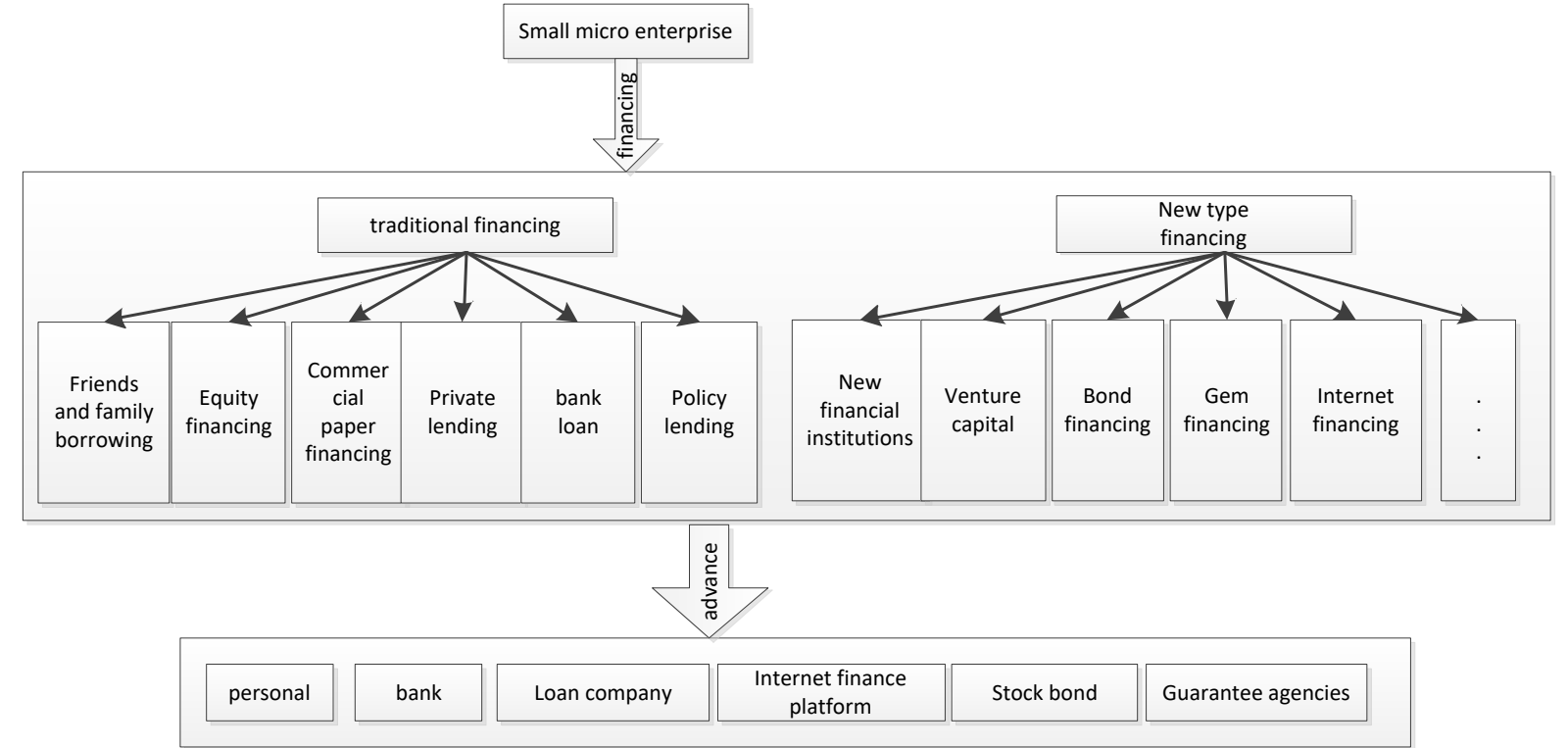

Figure 2. Financing mechanism of small and micro enterprises' innovation and entrepreneurship

\subsection{Innovation and entrepreneurship of small and micro enterprises}

Talent is the driving force of enterprise development. Only innovation and entrepreneurship can achieve core competitiveness. So, it is necessary for small and micro enterprises to formulate measures to attract talents and strengthen the innovation and entrepreneurship development of enterprises. The innovation and entrepreneurship of small and micro enterprises must conform to the economic development. This paper has formulated its driving mechanism as shown in figure 3.

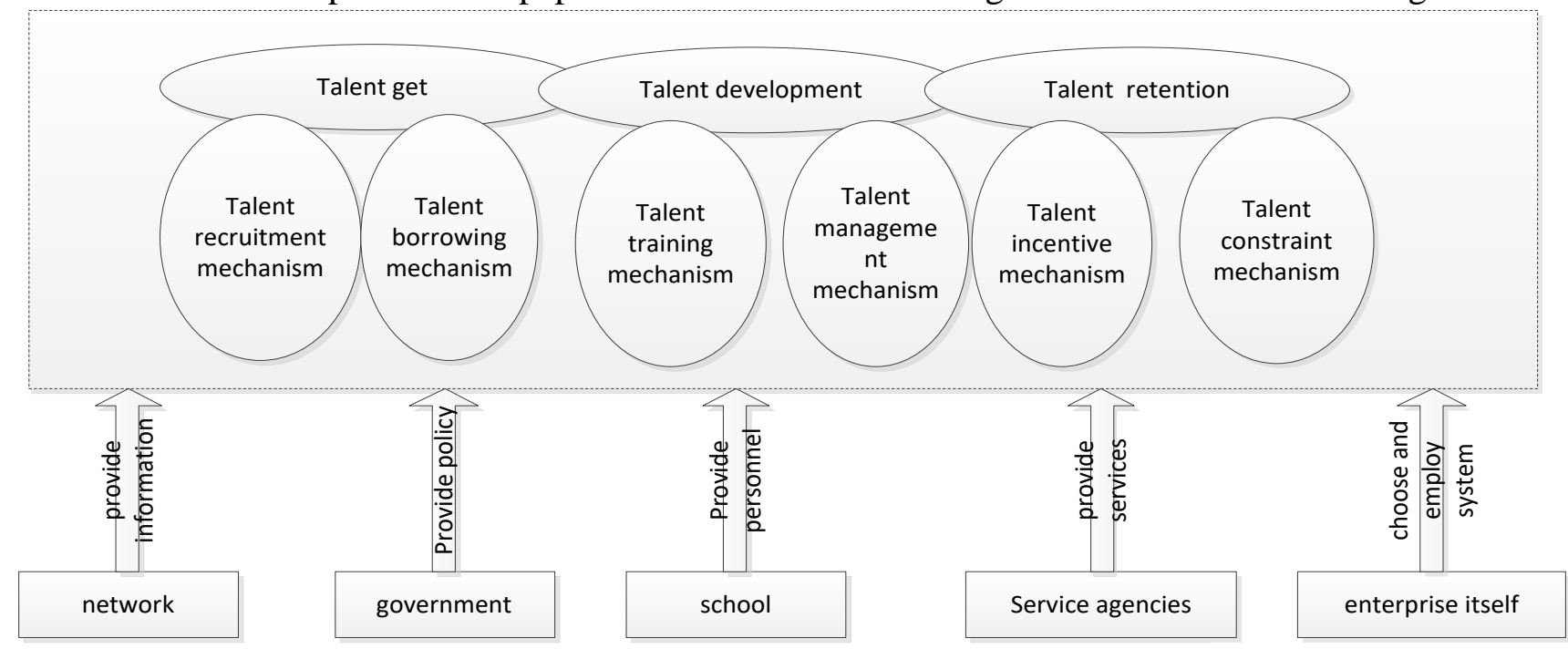

Figure 3. Innovation and entrepreneurship of small and micro enterprises

\section{Conclusion}

By analyzing the main problems of innovation and entrepreneurship of small and micro enterprises, this paper analyzes the elements of innovation and entrepreneurship environment of 
small and micro enterprises. Then, the present situation of small and micro enterprise innovation and entrepreneurship environment is analyzed in detail. This paper puts forward the optimization scheme of the process of promoting the innovation and entrepreneurship information release of small and micro enterprises and the approval process of registration registration. In view of the difficult and expensive financing of small and micro enterprises, a dynamic model of incomplete information of the three parties of small and micro enterprises, financial institutions and governments is constructed, and relevant Suggestions are put forward.

\section{References}

[1] Crossan M M, Marina A. A Multi-Dimensional Framework of Organizational Innovation: A Systematic Review of the Literature. Journal of Management Studies (2010), p. 1154 - 1191

[2] Lall S. Technological capabilities and industrialization (World Development), p. 165 - 186

[3] Leonard D A 1992 Core Capabilities and Core Rigidities: A Paradox in Managing New Product Development. Strategic Management Journal (2010), p. 111 - 125

[4] Teece D J. Profiting from technological innovation: Implications for integration, collaboration, licensing and public policy. Research Policy (2006), p. 285 - 305

[5] Teece D J. Competition, cooperation, and innovation: Organizational arrangements for regimes of rapid technological progress. Journal of Economic Behavior \& Organization (2012), p. 1 - 25

[6] Schumpeter J A. The Theory of Economic Development: An Inquiry into Profits, Capital, Credit, Interest, and the Business Cycle. Social Science Electronic Publishing (2004), p. 90-91 